\title{
Evaluating the HYPE model for estimating groundwater recharge in a groundwater dominated catchment in Poland
}

\author{
Dominika Bar-Michalczyk ${ }^{1,2}$, Tomasz Michalczyk ${ }^{1,2}$, \\ Stanisław Witczak ${ }^{1}$, Anna J. Żurek ${ }^{1}$ \\ ${ }^{1}$ AGH University of Science and Technology, Faculty of Geology, Geophysics and Environmental Protection; \\ al. A. Mickiewicza 30,30-059 Krakow, Poland; e-mail: bardominika@gmail.com \\ ${ }^{2}$ AGH University of Science and Technology, Faculty of Physics and Applied Computer Science; \\ al. A. Mickiewicza 30, 30-059 Krakow, Poland
}

(C) 2017 Authors. This is an open access publication, which can be used, distributed and reproduced in any medium according to the Creative Commons CC-BY 4.0 License requiring that the original work has been properly cited.

Received: 4 October 2017; accepted: 19 December 2017

\begin{abstract}
Hydrological models can be useful tools simulating climate and land use changes and their impact on nutrients outflows from a catchment area. One of them is the HYPE (HYdrological Predictions for the Environment) water quality model applicable to different spatial scales. Groundwater recharge via infiltrating precipitation is a significant water budget component. The rate of groundwater recharge in the HYPE model is estimated from the water balance in soils. The Kocinka river catchment is one of the test areas in the BONUS-Soils2Sea project where HYPE model modelling was carried out. A hydrograph, among others, is one of the modelling results and, based on it, the recharge rate of groundwater was determined. This value was compared with groundwater recharge rates estimated by the infiltration method used for the Groundwater Vulnerability Map of Poland.
\end{abstract}

Keywords: groundwater recharge, effective infiltration rate, HYPE, catchment scale

\section{INTRODUCTION}

The river catchment system is the basic element in both quantitative water management and the assessment of water quality (Sadurski \& Śmietański 2015, Sadurski \& Przytuła 2016). Groundwater recharge occurring through infiltrating precipitation is a significant water budget component. Climatic factors belong to the most important factors affecting infiltration rate (mostly precipitation and evapotranspiration) are soil properties, slope and land use of an area. The term "effective infiltration" used in Polish hydrogeology is related to actual recharge and refers to water movement below the root zone. In other words, it is the portion of the infiltrating water that reaches the aquifer. The total river outflow in Poland constitutes $30 \%$ of precipitation. Out of it, the contributions of the total surface runoff and the total groundwater flow are $13 \%$ and $17 \%$, respectively (Pazdro \& Kozerski 1991, Kleczkowski 2001). These proportions may vary considerably among the various catchments of the same climatic region. River flows in mountain catchments are mainly composed of an overland flow and a shallow subsurface flow. The opposite situation occurs in lowland catchments, where groundwater runoff dominates (Paczyński \& Sadurski 2007, Herbich \& Przytuła 2012, Przytuła et al. 2013). 
An example of the catchment with river discharge dominated by groundwater runoff is the Kocinka River catchment. This agricultural area is located within the Oder River basin in Southern Poland (Kaziuk \& Nowak 1999). The catchment is covered by $1-33 \mathrm{~m}$ thick Quaternary sediments of fluvio-glacial and aeolian origin, underlain by Upper Jurassic limestones (Paczyński \& Sadurski 2007). The Jurassic strata contain one of the largest groundwater bodies in Poland, i.e., the Major Groundwater Basin 326 E (MGWB 326 E; Kleczkowski et al. 1990). The Kocinka catchment is one of the case study areas of the BONUS-Soils2Sea project (www.soils2sea.eu). The research conducted there involves hydrometric measurements that include continuous recordings of the water level and flow of the river. Their preliminary results were presented by Michalczyk \& Bar-Michalczyk (2015), Zięba et al. (2015), and Michalczyk et al. (2016). The dominant role of groundwater in determining the outflow from the Kocinka catchment was confirmed by Wachniew et al. (2016). The hydrometric measurements were used for verifying the amount of groundwater runoff in the Kocinka catchment applying the hydrological HYPE model (HYdrological Predictions for the Environment) (see Donnelly et al. 2014, Højberg et al. 2017).

Many hydrological models refer to the water budget aspect of a catchment and are based on the physical description of the processes simulating the water budget. The review papers on the characteristics and tentative classifications of the models (Todini 2007, Healy 2010, Devia et al. 2015, Paniconi \& Putti 2015) show their immense differentiation, considering both the scale and the adapted methodology of research. According to Healy (2010), the water budget methods represent the largest class of techniques for estimating groundwater recharge. Drainage outflow below the bottom of the root zone may be an equivalent of recharge if the bottom of the soil column extends to the water table. The crucial role of soil in the infiltration process was also suggested by Staśko et al. (2012). Many catchment-scale hydrological models are commonly developed to describe mass transport within the basin. Hydrological models are widely used for assessing the impact of climate changes on the transport processes of water and biogenic substances. This concerns mainly the transport of nutrients, mostly nitrogen and phosphorus. Those models typically do not emphasize groundwater flow and, furthermore, the water budget is simulated in a simplified way. Detailed simulations of surface and subsurface processes require a large number of long-term daily climatic (e.g. average temperature, precipitation) and hydrological data (e.g. flow rate, concentration of nutrients). Hydrological models use meteorological, hydrological and soil databases spatially related using GIS (Geographic Information System) software. Examples of such models are MIKE SHE (Refsgaard \& Storm 1995), SHETRAN (Ewen et al. 2000), TOPMODEL (Beven et al. 1984), HBV (Lindström et al. 1997) and SWAT (Neitsch et al. 2002). The SWAT and HYPE models visualize the circulation of water and nutrients (nitrogen and phosphorus) starting from the catchment scale up to the continental scale (Abbaspour et al. 2015, Donnelly et al. 2014, 2016, Marcinkowski et al. 2016, Piniewski 2016, Sitek \& Ulańczyk 2016).

The possibility of using the HYPE model for evaluating effective infiltration was explored by comparing the respective calculations for the Kocinka river catchment using the E-HYPE v. 3.1.1 model with those determined using the infiltration method applied for the Groundwater Vulnerability Map of Poland (Witczak et al. 2011). The comparative period encompassed the years 1993-2002, for which the data for both methods are available.

\section{STRUCTURE OF THE HYPE MODEL AND THE ASSESSMENT OF EFFECTIVE INFILTRATION}

The HYPE model, based on the HBV model (Lindström et al. 1997), was developed in 2005-2007 by the Swedish Meteorological and Hydrological Institute (SMHI) and is dedicated to both small and large catchments. The main idea of its creation was the prediction of the impact of climate and land use changes on the aquatic system. The effects of these transformations are evaluated by changes of the water budget and the load of nutrients (nitrogen and phosphorus) flowing out from 
the catchment area (Donnelly et al. 2014, 2016). The HYPE has been designed as a dynamic model based on the daily water fluxes in catchments, as the intensity of the processes being modelled is highly variable in time and space.

The simplified structure of the HYPE is shown in Figure 1. The model simulates the water budget and mass transport mainly within soil profiles containing up to three soil layers, in rivers and in lakes. The structure of the model has been built in ASCII files, which can be edited in a simple way (Lindström et al. 2010). The model is still expanding and its program code is available under an open source license and can be found at a SMHI website (http://hypecode.smhi.se/) (Donnelly et al. 2014). Sub-basins are the main operational units in the HYPE model. They may be independent of each other or connected together by a surface water or a regional groundwater flow. For better representation of land use character, each subbasin can be further divided into classes with a unique combination of the soil type and land use, the socalled SLC classes (Soil type-Land use Combination). They represent the smallest spatial units in which calculations are performed. In other hydrological models (including the SWAT) (Abbaspour et al. 2015), the SLC classes are equivalents of the units called HRU (Hydrological Response Units) (Flügel 1995), which are treated as hydrologically homogeneous entities. The SLCs and the HRUs are virtual entities not located in the real geometry of the basin or subbasin. The data entered into the HYPE model contain information on the percentage contribution of each of the SLCs to the catchment area. The model is not spatially oriented, however essential input data, e.g., those on the soil type and its parameters, are obtained from the GIS system.

Groundwater flow in deeper horizons can be simulated in the HYPE model in two ways: using the Regional groundwater flow or Aquifer files (Fig. 1). Generally, in the Aquifer module it is possible to take into account the lag time of nutrient transfer from the root zone to the aquifer. The regional groundwater flow module enables the simulation of a groundwater exchange between various catchments. Both modules are still in the experimental stage. In the E-HYPE 3.1.1 many sub-catchments in Poland, including the Kocinka catchment, are still not connected to any deeper hydrogeological structure. It enables the water balance necessary to assess effective infiltration but additional experiments are necessary for simulating the transport of nutrients.

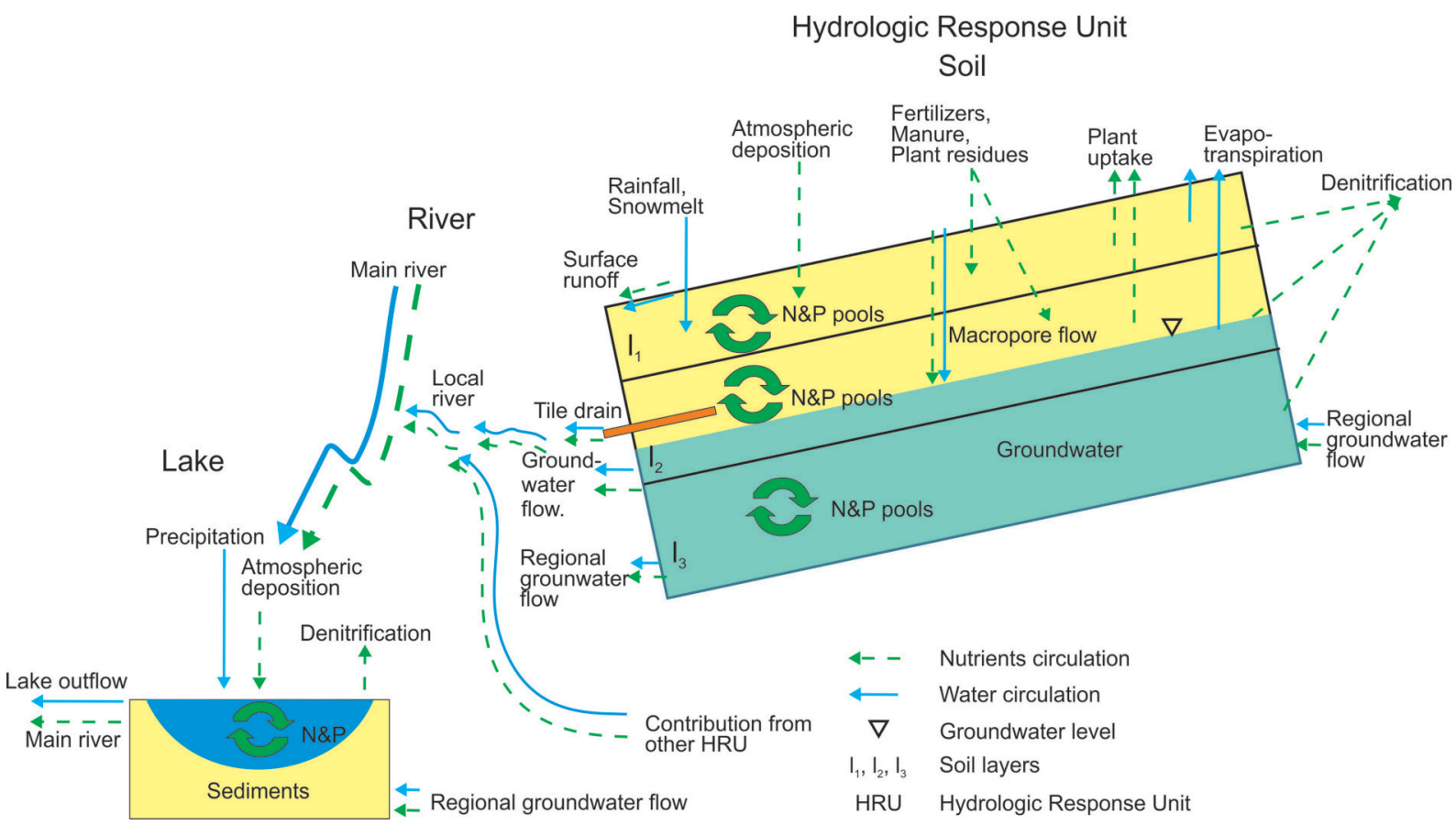

Fig. 1. The HYPE model structure including water circulation (blue line) and mass transport (green dotted line) processes (Donnelly et al. 2014, modified) 
In the HYPE model, the intensity of groundwater recharge by infiltration depends on the water budget. The volume of water in the soil profile increases due to rainfall or snow melting but is reduced by surface runoff or as a result of evapotranspiration processes. Part of the infiltrating water can also be discharged to watercourses by drain pipes (Fig. 1). Other processes included in the HYPE are evapotranspiration, surface erosion and macropore flow (Refsgaard et al. 2016). A soil profile of a particular SLC is simulated by a unique type of soil texture and is divided into a maximum three layers, each with an arbitrarily selected thickness. The soil types are characterized by many parameters, including those associated with moisture (retention). To the latter belong the wilting point $(w c w p)$, the water holding capacity $(w c f c)$, that is the fraction of soil available for evapotranspiration but not for runoff, and the effective porosity (wcep). Model parameters are either the same for the whole model domain, or for all the soil layers of the profile, or they change with depth. Typical model parameters are individually fitted to the soil type and land cover (SLC) (Donnelly et al. 2014).

Retention of water in the soil profile is calculated using the parameters related to moisture content and the thickness of each soil layer, while the initial value of soil moisture is assumed to be the total of the wilting point (wcwp) plus the water holding capacity $(w c f c)$. It is also possible to begin calculations providing that soil layers are fully saturated, then the initial water content is assumed as the effective porosity (wcep). When all the soil layers are fully saturated with water, which usually results from intense rainfall, water is discharged to a river as surface runoff.

Evapotranspiration depends on the moisture content of the soil layers and is calculated for the given time interval, according to Lindström et al. (2010) and the documentation of the HYPE model (Donnelly et al. 2014). The HYPE assumes that evapotranspiration takes place in the two upper layers of any soil profile (Fig 1). The calculations of the actual evapotranspiration are based on potential evapotranspiration (epot), which is in turn calculated using the average daily temperature. The volume of potential evapotranspiration depends on the SLC class and decreases exponentially with the depth of the soil profile. Evapotranspiration from the soil profile occurs when the air temperature is higher than the threshold temperature of evapotranspiration. In winter, the same threshold temperature for evapotranspiration is used to determine the snow melting point. The HYPE model allows the use of correction factors for evapotranspiration dependent on seasonal changes. These factors can correct the evapotranspiration values, increasing them in spring when the air is dry, and decreasing in autumn when the air is more humid. Evapotranspiration from soil layers takes place when the soil moisture content exceeds the threshold value corresponding to the wilting point (wcwp). If the moisture content is lower than the $w c w p$ value, evapotranspiration does not occur.

Effective infiltration is a term used in Polish hydrogeology to denote the volume of water that has infiltrated through the unsaturated zone and reached the groundwater. In the HYPE its equivalent is calculated from potential infiltration, i.e. the total of precipitation and snow cover, from which an amount of surface runoff can be deducted. In the next step, the formula takes into account the water holding capacity $(w c f c)$ and the wilting point $(w c w p)$. If the calculated value is higher than zero, the soil is saturated and the potential infiltration will infiltrate the upper soils layer. Evapotranspiration from the soil layer (evap) is limited by the availability of water in the soil above the wilting point. The actual evaporation rate is equal to potential evapotranspiration only if the water exceeds field capacity or a portion of field capacity. Evapotranspiration increases linearly between these limits. Infiltration from the top layer is considered in the HYPE model if all of the soil pores in this layer are fully filled with water and its moisture content and water holding capacity values are equal. The same happens in underlaying layers until water reaches the groundwater table. The groundwater level is calculated from the ratio of the volume of saturated pores to the effective porosity of all the soil layers together. When the groundwater level reaches the ditch level or the level of surface water, groundwater is discharged into a nearest watercourse. The HYPE model generates a hydrograph of daily flow of a river along its outflow from the subbasin.

In the last version of the HYPE model for the Baltic Sea region (E-HYPE version 3.1.1) calculations are made on a daily time step in coupled 
35,408 subbasins. The subbasin of the Kocinka river with an area of $260.48 \mathrm{~km}^{2}$ is close to the mean size of these catchments (Refsgaard et al. 2016). The HYPE hydrograph enables distinguishing the baseflow fraction of a stream flow which is practically equal to the groundwater outflow from the subbasin. The baseflow fraction of the stream flow is estimated in the HYPE by applying the baseflow filter BFLOW (Arnold et al. 1995). The authors used a simpler filter commonly used in Poland, which provides the value of groundwater outflow equal to the Mean Monthly Low Flow (MMLQ) value (Jokiel 1994).

In the HYPE modelling, the Kocinka catchment is unconnected to any deeper hydrogeological structure and it is not consistent with actual hydrogeology. Therefore, the HYPE modelling was evaluating only for estimating groundwater recharge. Figure 2 shows an example of dividing the Kocinka catchment area into the SLC classes made with ArcGIS 10.1 tools and based on the available information on the soil types and land use management practices.

The typical set of the SLC characteristics (soil type and land use) was extended with the data on the depth of water table. Such approach facilitates a subsequent parameterization of the catchment area. The SLCs for an arable land area (the upper part of the legend) are more detailed. Other Corine Land Cover Classes (CLC 2006, EEA) need individual characteristics of soil types, crops etc. After entering the required data and integrating surface waters with groundwater using the Aquifer file, the division of the Kocinka catchment into 38 units (Fig. 2) was made and used for subsequent model calculations.

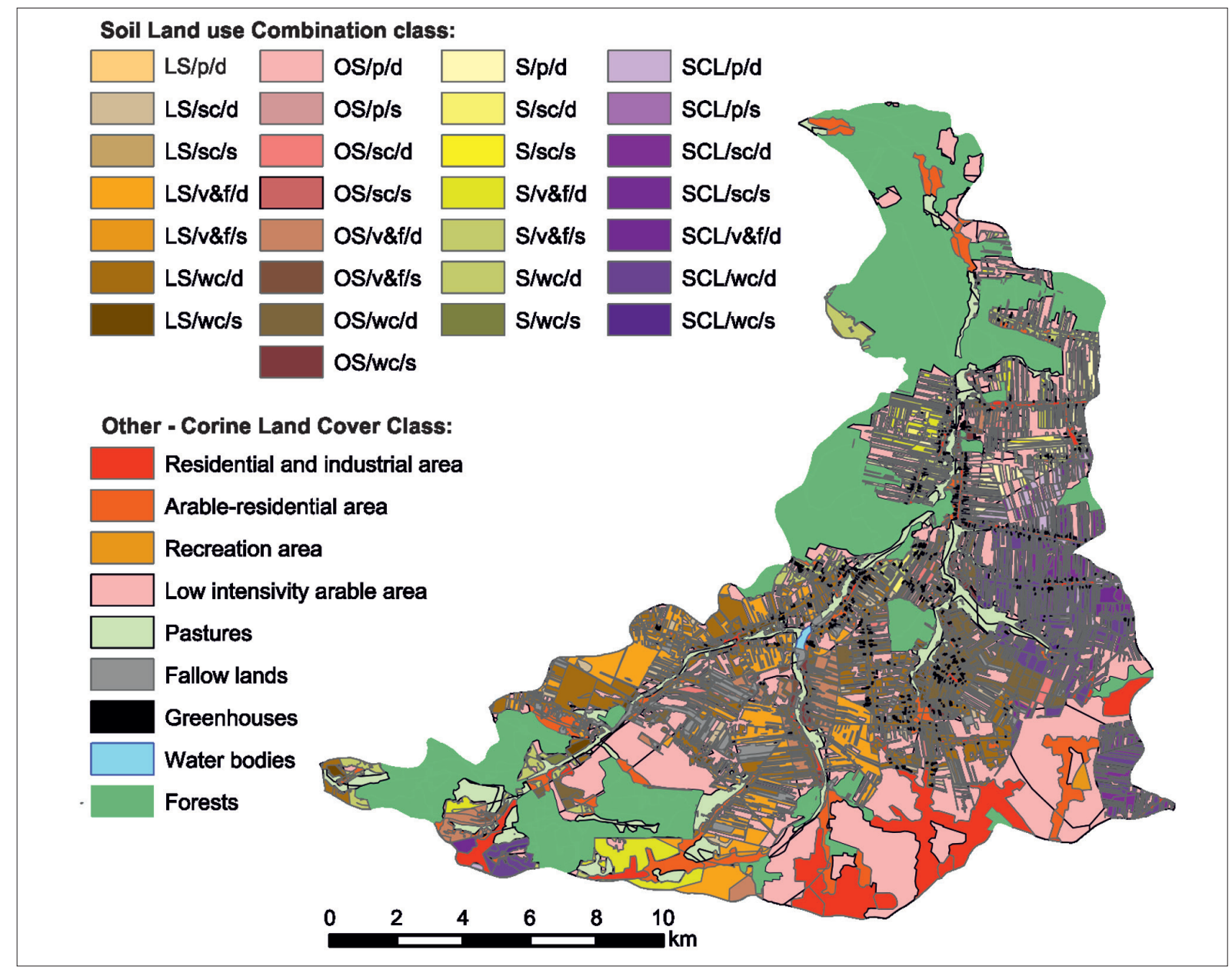

Fig. 2. Example of the determination Soil type Land use Combination (SLC) classes using ArcGIS in the Kocinka catchment area. Characteristics of SLC for an agricultural area: soil type/crop/depth to groundwater are given below. Soil types: LS - loamy sand, OS - organic soils, $S$ - sand, SCL - sandy loam. Crops: $p$ - potatoes, sc-summer cereals, wc - winter cereals, v\&f - vegetables and fruits. Depth to groundwater: $d->1.5 \mathrm{~m}, s-<1.5 \mathrm{~m}$ 
The HYPE model generates one hydrograph per subbasin. Due to separating the hydrograph into two components, i.e. the surface runoff and the groundwater outflow, it is possible to obtain recharge (effective infiltration) values. This allows the evaluation of groundwater outflow from catchment basins not provided by water gauges, or comparing and verifying observations accumulated previously. The existing HYPE database may be used, corrected and extended with new pieces of information, thus representing an additional source of data on groundwater resources.

\section{METHODS AND RESULTS}

In the HYPE model, infiltration is a part of the water flow and nutrient transport processes. The volume of infiltrating water depends on meteorological, land use and soil parameters. A similar method for estimating infiltration for a regional model on the basis of soil conditions was proposed by Staśko et al (2012). The calculation in the E-HYPE v. 3.1.1 (Donnelly et al. 2016) included the spatially and temporally variable rate of infiltration. The authors assumed that effective infiltration is a part of groundwater outflow originating from soil layers and directing to a water course. A volume of infiltrated water was calculated assuming that groundwater outflow is equal to the Mean Monthly Low Flow (MMLQ) (Fig. 3).

The ten-year average value of recharge rate at the Kocinka catchment area $\left(260.48 \mathrm{~km}^{2}\right)$ by infiltration and calculated from the MMLQ data amounts to $1.290 \mathrm{~m}^{3} / \mathrm{s}$ which corresponds to $156.2 \mathrm{~mm} /$ year. In turn, the ten-year average precipitation rate for the Kocinka catchment area according to the database of the HYPE files is $788.5 \mathrm{~mm} /$ year. Thus, the volume of the infiltration water recharging the Kocinka catchment (156.2 mm/year) makes $19.7 \%$ of the precipitation value, being strongly dependent on precipitation values in individual years (Fig. 4).

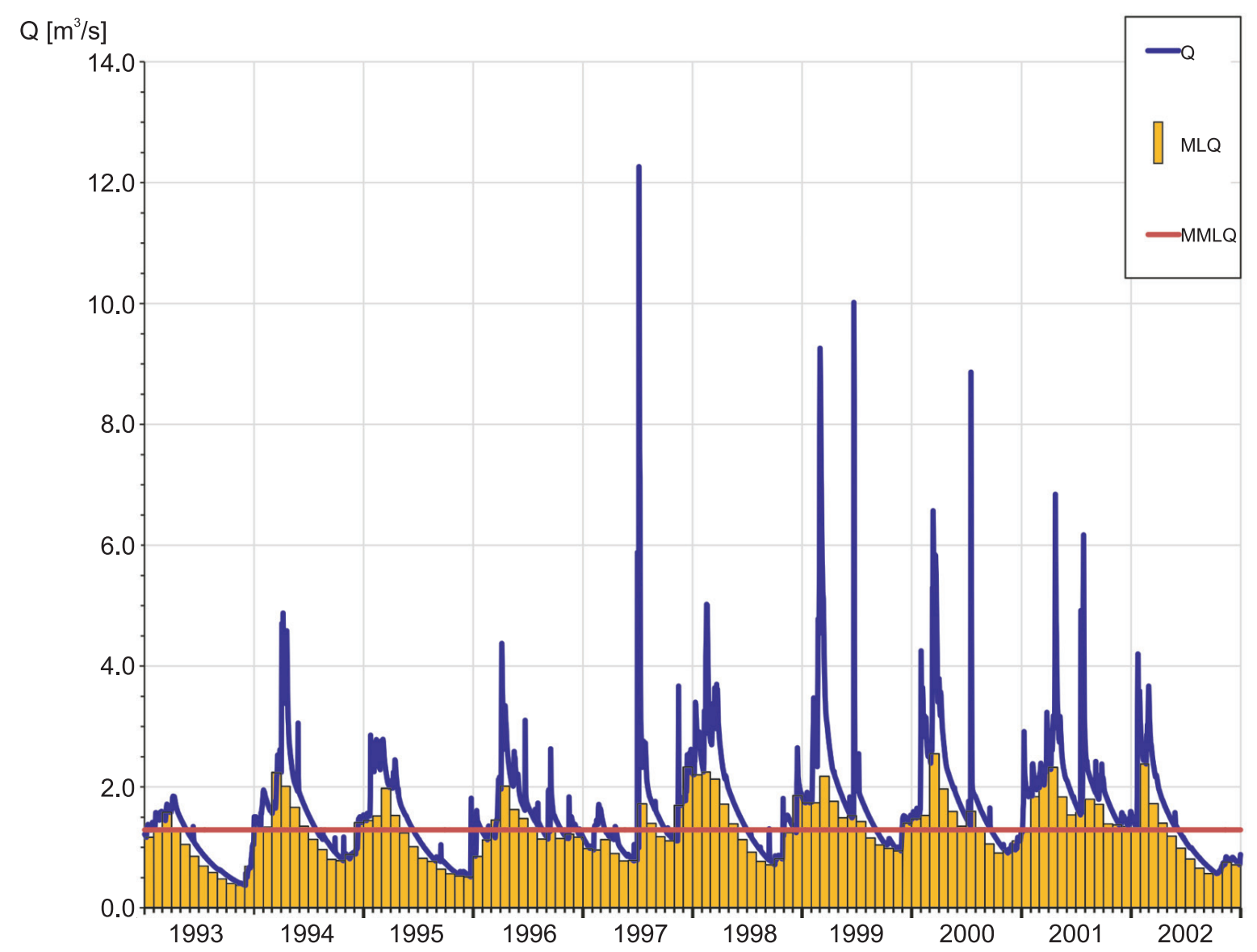

Fig. 3. Monthly Low Flow (MLQ) and the Mean Monthly Low Flow (MMLQ) calculated for the Kocinka river for the period 1993-2002. Hydrograph of daily stream flow (Q) according to the E-HYPE v. 3.1.1 model output file (Donnelly et al. 2016) 


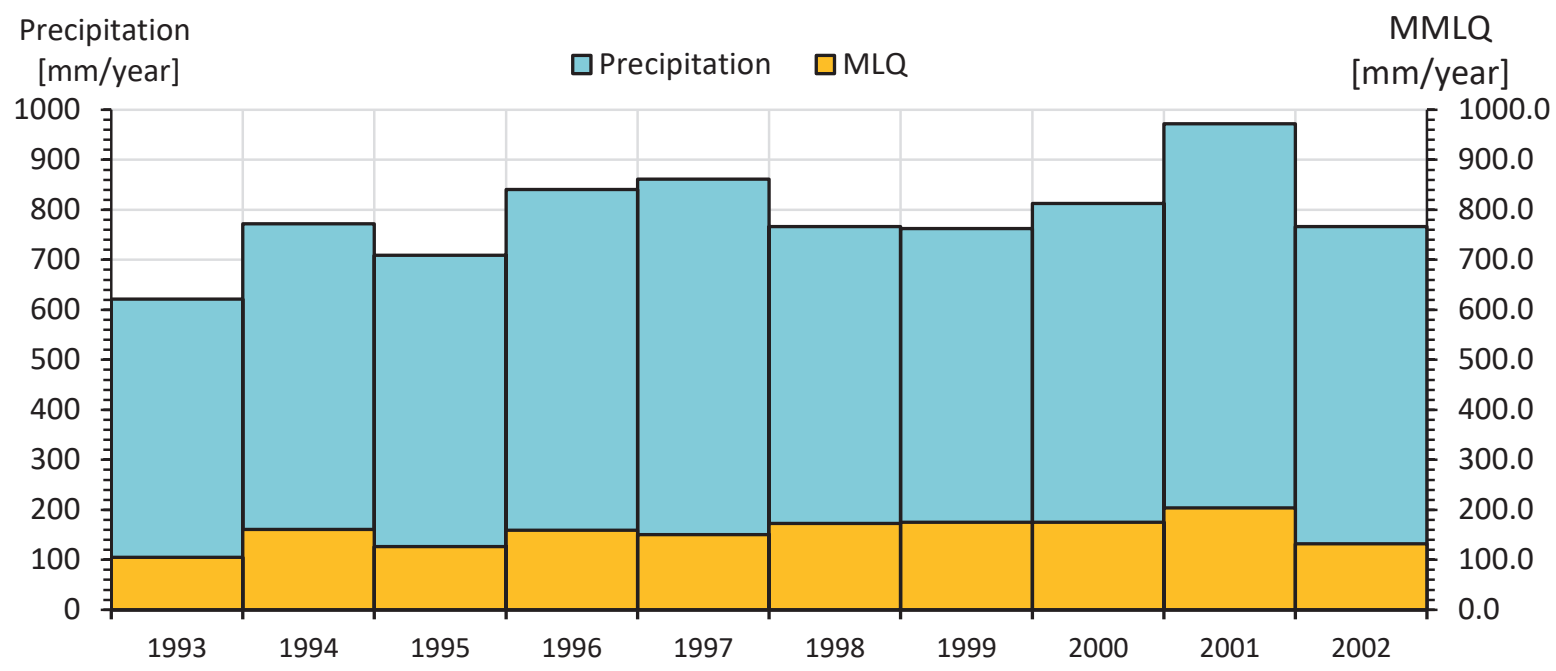

Fig. 4. Annual precipitation and annual effective infiltration calculated as the Monthly Low Flow (MLQ) for the Kocinka River during the period 1993-2002. Data from the E-HYPE v. 3.1.1 model output files (Donnelly et al. 2016)

The mean recharge rates obtained with the HYPE model for the Kocinka catchment were compared with those generated by the infiltration method used for the Groundwater Vulnerability Map of Poland (Witczak et al. 2011) for the period 1993-2002. Groundwater recharge for preparing this map was estimated with the operational method based on the effective infiltration rate. The expression used to derive the effective infiltration $R$ (groundwater recharge) of shallow aquifer systems in Poland reads as follows:

$R=P \alpha \beta \gamma \delta$

where:

$P$-annual precipitation for the period 19932002 [mm/year] (IMGW 2010),

$\alpha$-effective infiltration rate (infiltration coefficient) depending on the lithology of deposits $[-]$,

$\beta$-correction coefficient related to the type of land cover and land use [-],

$\gamma$-correction coefficient related to the slope of the land surface $[-]$,

$\delta$-correction coefficient related to the depth of water table $[-]$.

The distribution of average groundwater recharge $(R)$ during the period 1993-2002 according to the GVMP calculations was calibrated using the total groundwater runoff from the territory of Poland determined with the hydrological method. The trial-and-error method was adopted during the fitting procedure, modifying mainly the infiltration coefficient $(\alpha)$ which depends on the lithology of near-surface layers The final results for Poland are as follows: the average total effective infiltration is $31.515 \mathrm{~km}^{3} /$ year, which corresponds to $102.2 \mathrm{~mm} /$ year. The average effective infiltration makes $15.6 \%$ of the mean annual precipitation of $653.6 \mathrm{~mm}$ for the period 1993-2002.

The effective annual infiltration rate $R$ calculated for the Kocinka catchment area is equal $134.30 \mathrm{~mm}$ which amounts to $19.4 \%$ of the mean precipitation on this area. The values of effective infiltration obtained in the E-HYPE v. 3.1.1 and GVMP calculations differ from each other. This difference is due to the different values of average annual precipitation rates used in determining effective infiltration. However, the proportions between effective infiltration rates and precipitation rates are similar and amount to $19.4 \%$ in the case of the GVMP and $19.7 \%$ in case of the E-HYPE v. 3.1.1 model results.

The effective infiltration rates determined with the HYPE model are comparable with the groundwater recharge for the Kocinka catchment calculated from the information data package of the Groundwater Vulnerability Map of Poland (Witczak et al. 2011). Assuming that effective infiltration values for other catchments in 
the Polish part of the E-HYPE v. 3.1.1 model are also comparable, the authors suggest using the HYPE model as a good source of recharge calculation in the regional scale modelling. Such data enable the assessment of groundwater runoff and recharge for ungauged subbasins. An important element that can be derived from the HYPE model is the variability of infiltration over time, which is an essential feature in determining transient models.
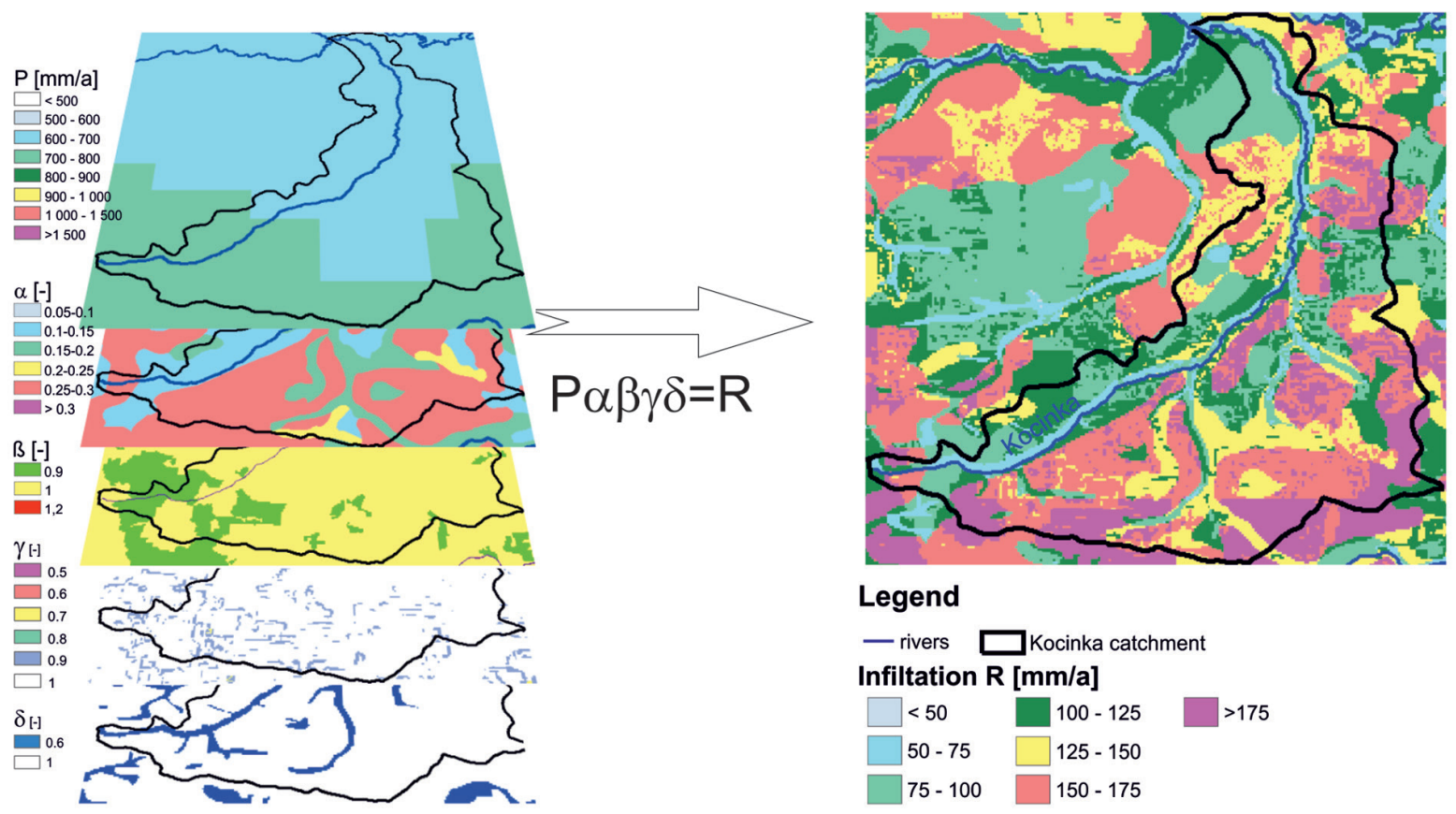

Fig. 5. Schematic diagram of the GIS layers used in the GVMP estimation of the effective infiltration for the Kocinka catchment (Duda et al. 2011, Witczak et al. 2011, modified)

\section{DISCUSSION AND CONCLUSIONS}

The HYPE model is a hydrological catchment model simulating the water budget and transport of nutrients (nitrogen and phosphorus). The model has been used in both local and regional scales in the project BONUS-Soils2Sea (Refsgaard et al. 2016). The modelling reveals that the E-HYPE v.3.1.1 database can be used for assessing groundwater recharge in the areas of Poland distinguished on the basis of river catchments.

The rules of the assessment of GW resources in water economy units in Poland needs two independent methods for establishing groundwater recharge rates (Herbich et al. 2013). In the authors opinion, the input data used for E-HYPE 3.1.1 (the European application), which are collected from different national and EU databases could be utilized for these purposes.

The "philosophy" of hydrological balance models, including the HYPE model, is very different from hydrogeological numerical models of the flow and mass transport. Hydrological balance models describe the processes of water circulation occurring on the surface and in the upper soil zone (often synonymous with a zone of soil or a root zone) in a fairly detailed way, taking into account the impact of vegetation, evapotranspiration and agricultural treatment. Simulations are carried out for daily time steps, because the processes being modelled are highly variable in space and time. For these reasons, hydrological balance models are commonly used for assessing the effects of climate changes on the processes of water budget and nutrients circulation.

The E-HYPE 3.1.1 model is a good tool for estimating the recharge rate at sub-catchment scale but the use of such models is limited when considering local-scale transport pathways in the subsurface. For this purpose, hydrogeological 3D flow and transport models are necessary. 
The work was carried out as a part of the $\mathrm{BO}$ NUS-Soils2Sea program and the statutory research of the AGH University of Science and Technology (Projects Nos. 11.11.140.797 and 11.11.220.01).

\section{REFERENCES}

Abbaspour K.C., Rouholahnejada E.S., Vaghefia S., Srinivasanb R., Yanga H. \& Kløve B., 2015. A continental-scale hydrology and water quality model for Europe: Calibration and uncertainty of a high-resolution large-scale SWAT model. Journal of Hydrology, 524, 733-752.

Arnold J.G., Allen P.M., Muttiah R. \& Bernhardt G., 1995. Automated base-flow separation and recession analysis techniques. Ground Water, 33(6), 1010-1018.

Beven K.J., Kirkby M.J., Schofield N. \& Tagg A.F., 1984. Testing a physically based flood forecasting model (TOPMODEL) for three UK catchments. Journal of Hydrology, 69, 119-143.

CLC 2006 - CORINE Land Cover. EEA Reports about Europe's environment. European Environment Agency, Committee of the European Communities, Copenhagen. Database for Poland. GIOŚ, Warszawa.

Duda R., Witczak S. \& Żurek A., 2011, Mapa wrażliwości wód podziemnych na zanieczyszczenie. Akademia Górniczo-Hutnicza im. Stanisława Staszica w Krakowie, Wydział Geologii, Geofizyki i Ochrony Środowiska, Kraków.

Donnelly C., Yang W. \& Dahnč J., 2014. River discharge to the Baltic Sea in a future climate. Climatic Change, 122, 157-170.

Donnelly C., Andersson J.C.M. \& Arheimer B. 2016. Using flow signatures and catchment similarities to evaluate the E-HYPE multi-basin model across Europe. Hydrological Sciences Journal, 61, 2, 255-273. DOI 10.1080/02626667.2015.1027710, [on-line:] http://hypeweb.smhi.se/europehype [access: 25.02.2017].

Ewen J., Parkin G. \& O'Connell P.E., 2000. SHETRAN: distributed river basin flow and transport modeling system. Journal of Hydrologic Engineering, 5, 250-258.

Flügel W., 1995. Delineating hydrological response units by geographical information-system analyses for regional modeling using PRMS/MMS in drainage-basin of the River Brol, Germany. Hydrological Processes, 9, 423-436.

Devia G.D., Ganasri B.P. \& Dwarakish G.S., 2015. A Review on Hydrological Models. Aquatic Procedia, 4, 1001-1007.

Healy R.W., 2010. Estimating Groundwater Recharge. Cambridge University Press, Cambridge.

Herbich P., Kapuściński J., Nowicki K. \& Rodzoch A., 2013. Metodyka określania zasobów dyspozycyjnych wód podziemnych $w$ obszarach bilansowych $z$ uwzględnieniem potrzeb jednolitych bilansów wodnogospodarczych. Poradnik metodyczny. Ministerstwo Środowiska, Warszawa.

Herbich P. \& Przytuła E., 2012. Bilans wodnogospodarczy wód podziemnych $z$ uwzględnieniem oddziaływań $z$ wodami powierzchniowymi $w$ dorzeczu Wisty. Informator Państwowej Służby Hydrogeologicznej. Państwowy Instytut Geologiczny - Państwowy Instytut Badawczy, Warszawa.
Højberg A.L., Hansen A.L., Wachniew P., Żurek A.J., Virtanen S., Arustiene J., Strömqvist J., Rankinen K. \& Refsgaard J.C., 2017. Review and assessment of nitrate reduction in groundwater in the Baltic Sea Basin. Journal of Hydrology: Regional Studies, 12, 2017, 50-68.

IMGW, 2010. Przeglądowa mapa rocznej sumy opadów atmosferycznych dla Polski [General map of average annual precipitation in Poland]. Instytut Meteorologii i Gospodarki Wodnej - Państwowy Instytut Badawczy, Kraków [unpublished].

Jokiel P.,1994. Zasoby, odnawialność i odplyw wód podziemnych strefy aktywnej wymiany w Polsce. Acta Geographica Lodziensia, 66/67, ŁTN, Łódź.

Kaziuk H. \& Nowak B., 1999. Szczegółowa mapa geologiczna Polski 1:50 000 wraz z objaśnieniami. Arkusz Ostrowy (809). PIG-PIB, Warszawa.

Kleczkowski A.S. (red.) 1990. Mapa obszarów głównych zbiorników wód podziemnych (GZWP) w Polsce wymagajacych szczególnej ochrony: 1:500 000 = The map of the critical protection areas (CPA) of the major groundwater basins $(M G W B)$ in Poland. Instytut Hydrogeologii i Geologii Inżynierskiej Akademii Górniczo-Hutniczej, Kraków.

Kleczkowski A.S., 2001. Ochrona hydrosfery i zasobów wód. [in:] Kotarba M.J. (red.), Przemiany środowiska naturalnego a ekorozwój, TBPŚ GEOSFERA, Kraków, 29-47.

Lindström G., Pers CH., Rosberg J., Stömqvist J. \& Arheimer B., 2010. Development and testing of the HYPE (Hydrological Predictions for the Environment) water quality model for different spatial scales. Hydrology Research, 41 (3-4), 295-319.

Lindström G., Johansson B., Persson M., Gardelin M. \& Bergström S., 1997. Development and test of the distributed HBV-96 hydrological model. Journal of Hydrology, 201, 272-288.

Marcinkowski P., Piniewski M., Kardel I., Srinivasan R. \& Okruszko T., 2016. Challenges in modelling of water quantity and quality in two contrasting meso-scale catchments in Poland. Journal of Water and Land Development, 31, 97-111. DOI: 10.1515/jwld-2016-0040.

Michalczyk T. \& Bar-Michalczyk D., 2015. Wyznaczenie punktów monitoringu badawczego wód podziemnych na podstawie czasu wymiany wód w zlewniach objętych badaniami modelowymi. Przeglad Geologiczny, 63 (10/2), 931-931.

Michalczyk T., Bar-Michalczyk D., Kania J., Malina G., Szklarczyk T., Witczak S., Żurek A., Różański K., Wachniew P. \& Zięba D., 2016. Ocena migracji azotanów w obszarze zasilania ujecia wód podziemnych Wierzchowisko w świetle badań projektu BONUS-Soils2Sea. [in:] Malina G (red.), Aktualne rozwiazania ujmowania i eksploatacji wód podziemnych: monografia, Polskie Zrzeszenie Inżynierów i Techników Sanitarnych, Oddział w Częstochowie, Częstochowa, 75-81.

Neitsch S.L., Arnold J.G., Kiniry J.R., Williams J.R. \& King K.W., 2002. Soil and Water Assessment Tool: Theoretical Documentation, Version 2000. TWRI Report TR-191. Water Resources Institute, College Station.

Paczyński B. \& Sadurski A. (red.), 2007. Hydrogeologia regionalna Polski. T. 1. Wody słodkie. Państwowy Instytut Geologiczny, Warszawa. 
Paniconi C. \& Putti M., 2015. Physically based modeling in catchment hydrology at 50: Survey and outlook. Water Resources Research, 51, 7090-7129.

Pazdro Z. \& Kozerski B., 1991. Hydrogeologia ogólna. Wyd. Geologiczne, Warszawa.

Piniewski M., 2016. Natural streamflow simulation for two largest river basins in Poland: a baseline for identification of flow alterations. Proceedings of the International Association of Hydrological Sciences, 373, 101-107.

Przytuła E., Filar S. \& Mordzonek G., 2013. Bilans wodnogospodarczy wód podziemnych $z$ uwzględnieniem oddziaływań $z$ wodami powierzchniowymi w polskiej części dorzecza Odry. Informator Państwowej Stużby Hydrogeologicznej. PIG-PIB, Warszawa.

Refsgaard J.C. \& Storm B., 1995. MIKE SHE. [in:] Singh V.P (ed.), Computer Models of Watershed Hydrology, Water Resources Publications, Colorado, USA, 809-846.

Refsgaard J.C., Jakobsen R., Hansen A.L., Højberg A.L., Żurek A.J., Różański K., Witczak S., Wachniew P., Donnelly C., Capell R., Bartosova A., Strömqvist J., Wörman A. \& Morén I., 2016 Up-scaling methodologies. BONUS Soils2Sea Deliverable 3.2. Geological Survey of Denmark and Greenland, Copenhagen, November, [on-line:] http://www.Soils2Sea.eu Access: [access: 25.02.2017].

Sadurski A. \& Przytuła E., 2016. Zasoby dyspozycyjne wód podziemnych dorzeczy w Polsce w świetle zrównoważonego gospodarowania wodami. Biuletyn Państwowego Instytutu Geologicznego, 466, 261-270.

Sadurski A. \& Śmietański L., 2015. Problem zasobów wód podziemnych. Przegląd Geologiczny, 63 (10/2), 1047-1052.
Sitek S. \& Ulańczyk R., 2016. Ocena zasilania wód podziemnych w zlewni rzeki Drama na podstawie modelu SWAT i metody infiltracyjnej. [in:] Witczak S. \& Żurek A. (red.), Praktyczne metody modelowania przepływu wód podziemnych, Akademia Górniczo-Hutnicza im. Stanisława Staszica w Krakowie, Wydział Geologii, Geofizyki i Ochrony Środowiska, Kraków, 231-238.

Staśko S., Tarka R. \& Olichwer T., 2012. Groundwater recharge evaluation based on the infiltration method. [in:] Groundwater Quality and Sustainability, IAH Selected Papers on Hydrogeology, 17, Taylor \& Francis Group, London, UK, 189-198.

Todini E., 2007. Hydrological catchment modeling: past, present and future. Hydrology and Earth System Sciences, 11, 468-482.

Wachniew P., Zięba D., Różański K., Michalczyk T., Bar-Michalczyk D., Kania J., Żurek A., Malina G. \& Witczak S., 2016. Wykorzystanie cieków powierzchniowych w monitorowaniu jakości eksploatowanych zbiorników wód podziemnych. [in:] Malina G. (red.), Aktualne rozwiązania ujmowania $i$ eksploatacji wód podziemnych: Monografia, Polskie Zrzeszenie Inżynierów i Techników Sanitarnych w Częstochowie, Oddział w Częstochowie, Częstochowa, 41-47.

Witczak S. (red.), 2011. Groundwater Vulnerability Map of Poland 1:500 000. Ministerstwo Środowiska., Warszawa.

Zięba D., Michalczyk T., Bar-Michalczyk D., Jaszczur M., Żurek A. \& Wachniew P., 2015. Rozpoznanie udziału wód podziemnych w odpływie ze zlewni rzecznej średniej wielkości. Przegląd Geologiczny, 63 (10/2), 1161-1165. 